\title{
АЛЕКСЕЙ ФЁДОРОВИЧ ЛОСЕВ: ЖИЗНЬ В МИФЕ
}

\begin{abstract}
Аннотация. В статье исследуются некоторые аспекты философского наследия Алексея Фёдоровича Лосева. За сложным научным понятийно-категориальным аппаратом его трудов сегодня чётко прослеживаются лейтмотивы веры, некогда скрытые от иензуры Советской России. Рассматриваются категории имени, мифа, истины, взятые в контексте важнейших трудов русского философа и древнейиих религиозно-философбких учений. Как современньй человек поймёт важнейший постулат А.Ф. Лосева, утверждаюший Имя в качестве Мифа, если в нашем сознании укоренилось, что миб - это искажённое представление о мире, иллюзия ослабшего ума, приравненная ко лжи сказка? Обосновывается, что философская система А.Ф. Лосева по-прежнему актуальна как в религиозно-филособском, так и в социокультурном смысле. Филособия Имени А.Ф. Лосева создана не как теоретический труд, но как результат обретённого в процессе ежедневной практики имяславия понимания сущности человеческой личности, божественной личности и их отношений посредством Имени Бога.
\end{abstract}

Ключевье слова: психология, философия, А.Ф. Лосев, иенности, Миф, Имя, Истина, личность, социум, праздник.

厅 ичность А.Ф. Лосева многогранна и загадочна, а потому интересна и привлекательна. Исследователи философского наследия А.Ф. Лосева обращали внимание на то, что религия, являясь стержнем всей его философской конструкции, принципиально раскрывается как символ в символе 1 . Учёные, анализирующие труды мыслителя в контексте русской религиозной философии, совершенно справедливо предлагают характеризовать этот символизм в связи со всепроникающими онтологическими связями ${ }^{2}$ и волевой устремлённостью3 ${ }^{3}$ Прежде и мы попытались объяснить магнетизм трудов А.Ф. Лосева как продиктованный жёст-

1 См., напр.: Гусев Д.В. Влияние исихастских традиций на философскую антропологию П.А. Флоренского и А.Ф. Лосева: дисс. ... канд. философских наук: 09.00.03. Орел, 2001. С. 54.

2 См.: Чупахина Н.А. Диалектика имени А.Ф. Лосева в контексте русской религиозной лингвофилософии: дисс. ... канд. философских наук: 09.00.03. СПб., 2007. С. 83.

3 См.: Петраков А.А. Проблема символа в русской философии XX в. (П.А. Флоренский, А.Ф. Лосев, С.Н. Булгаков, А. Белый): дисс. ... канд. философских наук: 09.00.13. М., 2006. C. 56-57. кой цензурой символизм, скрывающий что-то одинаково родное и истинное 4 . В этих ракурсах заслугой русского философа признаётся раскрытие символа в качестве механизма, вовлекающего человека посредством его сознания в реализацию искомого и ожидаемого им бытия. Однако объяснение зашифрованности и многослойности понятийно-категориального аппарата трудов А.Ф. Лосева в качестве уникального метода интерпретации христианского учения, по нашему мнению, не столько ограничивает их ценность, сколько искажает их суть. Стремился ли Алексей Фёдорович Лосев быть добросовестным учёным, последним философом Серебряного века или убеждённым христианином, верным своим монашеским обетам? Ответ на этот вопрос видится нам в исследовании творчества А.Ф. Лосева через призму мифа, фундаментом и ключом к пониманию которого выступает философия имени.

Имя - это не идея, а её особая бытийная модификация, и потому считать, что имена есть только нечто абсолютное, совершенное, иное по отношению к этому

\footnotetext{
4 См.: Омельчук Р.К. Онтология веры в философском наследии А.Ф. Лосева // Психология и психотехника. 2011. № 11 (38).
} C. $15-25$.

Статья подготовлена при поддержке грантов РГНФ

(проекты № 11-33-00111/13 «Междисциплинарное исследование социокультурных механизмов преемственности ценностей» и № 11-33-00701м «Научное исследование по философии в направлении «Онтология веры в свете философского наследия А.Ф. Лосева»») 


\section{Философия и психология}

миру, по мнению А.Ф. Лосева, значит искажать истину и удаляться от понимания роли имени в становлении целостной личности. Последовательно разбирая такие существенные моменты имени, как фонема, семема, этимон, морфема, симболон, ноэма, идея, энергема, интеллигенция, мыслитель обозначает 67 ступеней на пути к совершенной самореализации личности. Однако не стоит упускать из виду, что философия имени для А.Ф. Лосева являлась не только областью философских исследований, но и «исповеданием веры ${ }^{5}$. Подчеркнём, что глубина философии имени достигается мыслителем посредством ономатодоксии - имяславия, или прославления божественного имени: «не только одна мысль, одно воспоминание, одно произношение Имени Божия доставляет носителям таких имён благословение Божие, но что Имя Божие, реальная сила, всегда сопровождает такого носителя на всех путях его жизни и что этим он особенно и поставляется в общение с Господом» ${ }^{6}$. Прославление Имени, основанное на древнейшем религиозном фундаменте, глубочайшим образом проанализировано русским философом. Как известно, А.Ф. Лосев выделяет в имени три основных аспекта: смысловой (световой), энергийный и телеологический, соединяющиеся в цельном значении Имени. В конечном счёте, Имя понимается им как «то светлое и божественное бытие, к которому движется всякое иное бытие, и которое как бы издали руководит миром и привлекает его к себе» ${ }^{7}$. Русский философ затрагивает вопросы понимания имени, активного отношения к имени и, наконец, прямого служения имени ${ }^{8}$ : «сущность дела Павла - в служении Имени» ${ }^{9}$

Известный тезис, положенный в основу имяславия: Имя Божье есть Сам Бог, - существенно углубляется А.Ф. Лосевым. Мысля шире догматической религии и формального философствования, он констатирует: Имя есть Миф. Однако, возникает вопрос: как понимать такое утверждение современному человеку, в чьём сознании миф - это искажённое представление о мире, иллюзия ослабшего ума, приравненная ко лжи сказка?

Прежде всего, отметим, что для русского философа категории «имя», «миф» и «истина» если не тождественны полностью, то, несомненно, тесно связаны. Троичная ис-

5 См.: Чупахина Н.А. Диалектика имени А.Ф. Лосева в контексте русской религиозной лингвофилософии: дисс. ... канд. философских наук: 09.00.03. СПб., 2007. С. 88.

6 Лосев А.Ф. Вещь и имя. Самое само / подг. текста и общ. ред. А.А. Тахо-Годи, В.П. Троицкого; вступ. ст. А.Л. Доброхотова ; комм. А.С. Яковлева. СПб.: Изд-во Олега Абышко, 2008. C. 133.

7 Там же. С. 176

8 Там же. С. 177-178.

9 Там же. С. 174. тина в интерпретации А.Ф. Лосева проста и существенна: «одно», «образ» и «становление», или «моменты генологический, эйдетический (в узком смысле) и идеальновременной» ${ }^{10}$ - так мыслитель «зашифровал» Троицу в общепринятые категории античной философии. Истина, Божественное, принимает у него различные ипостаси, сокрытые в категории имени. Так, первым аспектом Истины является Единое («одно»), вторым - частное, локализованное («образ»), третьим - личное («становление»). На первый взгляд парадоксально то, что у А.Ф. Лосева Абсолютная Личность раскрывается именно как становление, символизирующее Святой Дух, а вовсе не как Единое, символизирующее Бога-Отца. Однако отметим, что «одно» указывает на первооснову, причину всех причин, корень всего сущего, а «становление» - на качественную, ценностную характеристику этого сущего. Раскрывая суть становления, русский философ передаёт атмосферу духовной реальности (мифа), пропитанную и определяемую сознанием Абсолютной Личности (Мифа).

Становление характеризуется мыслителем как одновременный покой и изменение, однако оно не тождественно бесконечному выходу за пределы себя и вечному возвращению к себе же (так А.Ф. Лосев определяет Единое), поскольку в этом случае не происходит качественного изменения в понимании Истины. «Одно», «Образ» и «Становление» - три аспекта Абсолютной Истины, представляющие одно и то же с различных точек зрения. По нашему мнению, становление у А.Ф. Лосева правильнее понимать через призму множественности имён, имеющую непосредственное отношение к разнообразию духовного со-бытия: «сущность, как имя, прежде всего требует именуемого различия, раздельности, а это значит, что она есть преименитая, неименуемая сущность и в то же время содержит в себе множество имён, она есть цельное имя и множество частных имён, определённое имя и беспредельное множество имён» ${ }^{11}$. Отсюда становится ясно, что различные имена суть различные типы отношений, обусловленные различной дистанцией с Истиной, а мифэто соответствующая социокультурная реальность, основанная на такого рода взаимоотношениях.

Приведём конкретные примеры. С одной стороны, в сознании древнего грека «силы природы не только одушевлены, но, будучи одушевлёнными, находятся между собой в очень определённых взаимоотношениях» ${ }^{12}$.

10 Лосев А.Ф. Античный космос и современная наука // Бытие - Имя - Космос / сост. и ред. А.А. Тахо-Годи. М.: Мысль, 1993. С. 133.

11 Там же. С. 160.

12 Лосев А.Ф. Античная философия в ее историческом развитии. М.: Государственное учебно-педагогическое издательство, 1957. С. 8. 


\section{Психология и психотехника 5(56) • 2013}

Такое одушевление не имеет ничего общего с гипостазированием, поскольку сущность последнего не связана с мифом. Миф, следовательно, характеризуется именно системой отношений, а точнее - культурой, поэтому для А.Ф. Лосева неприемлемо рассмотрение мифа как отвлечённо-идеального бытия: «миф - не идеальное понятие и также не идея и не понятие; это есть сама жизнь» ${ }^{13}$. С другой стороны, та интуиция, которую мыслитель так тонко чувствовал в античной культуре, некогда была присуща и русскому человеку, традиционно живущему рука об руку с чудом. Так, В.В. Бибихин, вспоминая слова А.Ф. Лосева, отмечал: «русский человек материалист, ему то́, что есть, что можно потрогать, то́ и истина» ${ }^{14}$. Для А.Ф. Лосева «материализм основывается как раз на сверхчувственной, и притом чисто интеллектуальной, интуиции» ${ }^{15}$, а «материя есть то, что мы воспринимаем внешними чувствами» ${ }^{16}$. Однако у В.В. Бибихина скорее имелся в виду не отрицающий иррациональное материалист, а реалист, значимой составляющей как личной, так и общественной жизни которого является божественное и святое. По крайней мере, русский человек, как и всякий другой человек, жил в мифе до тех пор, пока не начал овеществлять, абсолютизировать и обожествлять частное, относительное, помещая его на место абсолютного. В истории человечества такая механистичность сознания порождалась мифом о «рае на земле», достигаемом инквизицией и крестовыми походами, мифом о «безграничном могуществе человеческого разума», достигаемом «сатанинской» эксплуатацией природы и человека ${ }^{17}$, мифом о "светлом будущем», достигаемом революцией и террором ${ }^{18}$ и проч. В целом А.Ф. Лосев подчёркивал то, что путь буржуазной Европы отличается са́мой абстрактной и бездушной культурой ${ }^{19}$, диалектически противоположной неподвластной времени культуре мифа.

13 Лосев А.Ф. Диалектика мифа. Дополнение к Диалектике мифа / сост., подг. текста, общ. ред. А.А. Тахо-Годи, В.П. Троицкого. М.: Мысль, 2001. С. 40.

14 Бибихин В.В. Алексей Федорович Лосев. Сергей Сергеевич Аверинцев. М.: Институт философии, теологии и истории св. Фомы, 2006. С. 8.

15 Лосев А.Ф. Диалектика мифа. Дополнение к Диалектике мифа / сост., подг. текста, общ. ред. А.А. Тахо-Годи, В.П. Троицкого. М.: Мысль, 2001. С. 140.

16 Там же. С. 141.

17 См.: Там же. С. 257.

18 См.: Там же. С. 145.

19 Лосев А.Ф. Вещь и имя. Самое само / подг. текста и общ. ред. А.А. Тахо-Годи, В.П. Троицкого; вступ. ст. А.Л. Доброхотова ; комм. А.С. Яковлева. СПб.: Изд-во Олега Абышко, 2008. C. 27.
Миф как реальное и одновременно истинное бытие ценностно переживается в процессе свободных субъектно-субъектных взаимоотношений, которые не имеют иного основания, кроме себя. Миф - это царство не только истины, но и царство абсолютного доверия, царство правдивых отношений. Как отмечает А.А. Тахо-Годи, «по Лосеву, миф - не бесплодная выдумка и беспредметная фантазия, а предмет веры в чудесное, которое является человеку как неприложимый факт» ${ }^{20}$. Наличное, обыденное бытие противопоставляется мифу настолько, насколько наличность характеризуется отсутствием веры, правды и истины. Более того, если миф утверждает ценность уникальной личностной индивидуальности как фундамента для любого типа взаимоотношений, то наличность утверждает онтологический плюрализм бесконечного множества иных ценностей. Именно наличная обыденность рассматривает миф как фантазию, т.е. не существующее в действительности, воображаемое. Миф, высказанный или понятый через призму наличной обыденности, воспринимается как отход от реальности, однако усомниться в реальности мифа - значит усомниться в реальности истины. Таким образом, постановка вопроса о мифе - это постановка вопроса о бытийных ценностях, постановка вопроса о существовании истины в онтологическом аспекте, постановка вопроса о выражаемом в имени совершенном отношении.

Из вышесказанного следует, что А.Ф. Лосев отводит имени колоссальную роль в социальной действительности, поскольку его личностная природа объективна. Имя всегда личностно: на обыденном уровне оно неразрывно связано с конкретной личностью (например, Пьер Безухов), на социальном - с конкретным типом межличностных отношений (например, Петя, Пьер Безухов, Пётр Кириллович, граф Пётр Кириллович Безухов и т.п.). Если в «Философии имени» С.Н. Булгакова приводится 60 Имён Бога, встречающихся только в православных богослужебных молитвах ${ }^{21}$, то, учитывая многообразие религий, можно говорить о гораздо большем количестве уникальных личностных типов отношений человека и Бога посредством Его Имени. Так, например, санскр. Кана - «Ненаглядный», Джаганнатха - «Повелитель Вселенной», Патита-Павана - «Спаситель самых падших»; санскр., пали Татхагата - «Знающий истинный путь», Махавира - «Великий Герой», Джина -

Тахо-Годи А.А. Гомер, или чудо как реальный факт // Лосев А.Ф. Гомер; предисл. А.А. Тахо-Годи. 2-е изд., испр. М.: Молодая гвардия, 2006. С. 5-6.

21 См.: Булгаков С.Н. Философия Имени. СПб.: Наука, 1998. C. $416-418$. 


\section{Философия и психология}

«Победитель»; ивр. Элохим - «Бог богов», Эммануил (Христос) - «с нами Бог»; греч. Параклит - «Утешитель» (Святой Дух), Альф $а$ - «Начало всех начал»; араб. Аль-Мумин - «Дарующий защиту», Аль-Хади - «Направляющий», Ащ-Шахид - «Свидетельствующий»; аст. Уитцилопчтли - «Вдохновляющий сражаться»; древнеиран. Ахура Мазда - «Мудрый творец мысли». Крайне важно подчеркнуть, что в некоторых случаях перечисленные имена относятся к совершенно разным личностям, почитаемым в качестве Верховной Личности, Бога, поэтому в отдельных ситуациях, обязательно требующих от каждого человека глубокого погружения в соответствующие культурные традиции, имеет место уже не теоцентризм, а эгоцентризм или демонизм, тактично обозначенные философом в качестве «собственной оригинальной веры атеиста»²2. Однако с А.Ф. Лосевым нельзя не согласиться в отношении того, что «абсолютная мифология есть персонализм» ${ }^{23}$. Философ также подчёркивает, что «знать это имя и произносить его означает то же, что стать в теснейшее соприкосновение с бытием и могуществом Божиим и усвоить себе его полноту власти» ${ }^{24}$. Однако Имя, рассматриваемое русским мыслителем как Миф, не столько обобщает представления всякого религиозного человека, сколько раскрывает их сущностную и ценностную стороны. В этом случае Имя не отражает, а формирует социокультурную реальность, бытийно-ценностно определяя её уникальность и неповторимость.

Жизнь в мифе можно сравнить с единением в празднике: переживаемое в мифе единение в ценностях и желаниях тождественно достигаемому в празднике единению в песне и танце. Определение Э. Кассирером мифа как «интуитивного единства» ${ }^{25}$ весьма точно подходит для того, чтобы охарактеризовать сущность праздника. В целом праздник является живым мифом: в мифе, как и в празднике, каждая личность естественным образом обретает своё истинное положение, добровольно стремясь поклоняться, служить, жертвовать и в то же самое время переживать радость, испытывать удовлетворение, обмениваться положительными эмоциями. Праздничный танец - это не игра

22 Лосев А.Ф. Диалектика мифа. Дополнение к Диалектике мифа / сост., подг. текста, общ. ред. А.А. Тахо-Годи, В.П. Троицкого. М.: Мысль, 2001. С. 134-135.

23 Там же. С. 222.

24 Лосев А.Ф. Вещь и имя. Самое само / подг. текста и общ. ред. А.А. Тахо-Годи, В.П. Троицкого; вступ. ст. А.Л. Доброхотова ; комм. А.С. Яковлева. СПб.: Изд-во Олега Абышко, 2008. C. 139.

25 Кассирер Э. Философия символических форм. Т. 2: Мифологическое мышление. М.; СПб.: Университетская книга, 2002. C. 85 в соответствии с ролью, а именно импровизированная игра, которая обычно происходит между старыми и давно знакомыми друзьями. Вживание в игру, когда игра становится жизнью, а вера - истиной, и есть то преодоление разделения понятий «быть» и «играть», благодаря которому ценности становятся неотъемлемыми и естественными.

Однако нужно заметить, что миф и праздник всётаки отличаются друг от друга, поскольку единство, достигаемое в празднике, носит несколько условный характер. Праздник представляет собой своеобразный тест, выявляющий «единомышленников», а точнее «единовериев», которые также принимают воплощенные в песнях, танцах, подарках, смехе смыслы и ценности. Царящее на празднике единство достигается только благодаря тому, что степень такого принятия каждым празднующим остается скрытой, в то время как конкретизация субъективности и уникальных качеств героя праздничного торжества выявляет и конкретную дистанцию между ним и каждым празднующим. Если праздник - временное действо, то миф - постоянное настроение праздника, состояние сознания, которое можно обозначить как праздник каждый день, или, точнее, - как праздник души.

Для праздника души, как и для мифа, не существует времени, не существует рациональных законов и схем, не существует каких бы то ни было разделений и условностей. Ещё более существенным является присутствие в мифе и празднике благоприятной атмосферы для полного раскрытия и самореализации каждой личности. Отсутствие в мифе проявлений эгоизма и индивидуализма вовсе не является условием раскрытия и самореализации, поскольку эгоизм и индивидуализм преодолеваются праздничным настроением при вовлечении каждой личности целиком во всеобщее единение вокруг героя. Поскольку для наслаждения героя от каждой личности требуется напряжение всех душевных сил, любые проявления индивидуальности способствуют поднятию общего духа и воспринимаются не как эгоизм, а как служение. Таким образом, вовлечение в праздничные танец и песню становится не просто следованием за потоком чувств и аффектов и даже не укрощением этого потока, а трансформацией, преобразованием эгоистического стремления наслаждаться праздником в стремление наслаждать. Для самой личности возможность самореализоваться через праздничное действо является наиболее эффективным способом раскрытия собственной уникальности и актуализации собственного потенциала.

Таким образом, праздник, как и миф, представляет собой воплощение личностной мечты в настоящем. Направленная в будущее, мечта реализуется в поступках и 


\section{Психология и психотехника 5(56) • 2013}

делах - в этом её существенное отличие от бесплодной фантазии. Если мечта связана с достижением реальных целей и характеризуется готовностью прилагать реальные усилия, то фантазия в большей степени концентрирует внимание субъекта на собственном статусе, затеняя и размывая очертания так называемой «желанной» цели. В мифе герои всегда остаются героями, не затеняя друг друга и не теряя собственного уникального лица, фантазия же обречена оставаться только фантазией из-за неадекватной оценки себя, возникающей из завистливого желания стать центром, осью.

Идея праздничного хоровода не случайно заинтересовала А.Ф. Лосева ${ }^{26}$. Возможно, как и П.А. Флоренский, мыслитель обратил внимание на то, что «культ - cultus от collere - вращать - есть круговорот, хоровод, обращение вокруг святой реальности, вокруг святыни» ${ }^{27}$. Праздничный хоровод символичен: взявшись за руки, люди образуют круг - символ времени и вечности, символ перевоплощения и трансформации, символ Солнца и очищения. Участие в хороводе, сопровождаемом песнопениями и танцами, - это не просто приближение к истине, это и есть переживаемая в качестве мифа истина. Желания в мифе просты и естественны: всегда быть вместе, быть счастливыми и радующими друг друга. В мифе не требуется искусственного выхода за пределы себя, поскольку здесь, как и в хороводе, личность обретает физически, ментально, эмоционально и вербально, целиком вовлекаясь в бытие смысла. В мифе требования личности направлены в первую очередь не на других, а на себя: желание быть вместе с любящими, счастливыми и радующими людьми побуждает личность любить, радовать, приносить счастье. Более того, в основании мифа функционирует следующий механизм: непреодолимое желание отдавать, наслаждать и служить, естественно возникающее в результате привлечённости непревзойдёнными личностными качествами Другого как героя, друга, возлюбленного, раскрывает эти качества в личности того, кто реализует эти желания с любовью. Так, например, А.Ф. Лосев отмечает, что в дионисизме «происходит воссоединение человека с человеком и с природой» ${ }^{28}$. Вера в Дионисия, личность которого символизирует присущие природе производительные силы, а также телесный экстаз и чувственную оргийность, приводит к единению и гармонии

26 Лосев А.Ф. Эстетика хороводов в «Законах» Платона // Античность и современность. М.: Наука, 1972. С. 133-153.

27 Флоренский П.А. Философия культа (Опыт православной антроподицеи) / сост. и коммент. С.М. Половинкин, игумен Андроник (Трубачев). М.: Российская политическая энциклопедия (РОССПЭН), 2010. С. 143.

28 Лосев А.Ф. Очерки античного символизма и мифологии / сост. и общ. ред. А.А. Тахо-Годи. СПб.: Алетейя, 1993. С. 30. с природой, а также характерным для этого телесной силе, здоровью и красоте, а ведь это и есть ценности, перенимаемые от природы. Отсюда и «религия тела» как определение дионисизма А.Ф. Лосевым ${ }^{29}$.

Философское наследие русского мыслителя позволяет однозначно утверждать, что реализация данного механизма начинается посредством служения Имени Бога как величайшего героя, ближайшего друга, единственного возлюбленного. А.Ф. Лосев видел цель всякого призывания Имени Божия именно в «некоем отождествлении себя с этим Именем»: «Цель молитвы, да и всего религиозного опыта (если только последний чем-нибудь отличается от молитвы), состоит в таком отражении на себя Божества, когда уже ничего в человеке не остается человечески-неустойчивого и человечески-неустроенного и когда человек всецело есть только образ Божий» ${ }^{30}$. Упомянутые выше механизмы, обнаруженные и характеризуемые философом, позволяют развить его идеи.

По аналогии: служение Имени Драгоценнейшего Просветлённого Будды (санскр. Ом мани падме хум - «О, Драгоценность, восседающая на лотосе!») будет способствовать возвышению личности через постепенное пробуждение и просветление разума вплоть до полного освобождения от приносящих страдания повторяющихся рождения и смерти; служение Имени Единого и Единственного Аллаха (араб. Аллаху Акбар — «Аллах велик!») будет способствовать возвышению личности через постепенное вверение себя Ему и развитие личной преданности в качестве Его нижайшего слуги; служение Имени Богочеловека Иисуса Христа (церк.-слав. Господи Иисусе Христе Сьне Божий помилуй мя грешнаго - «Господь Иисус Христос, Сын Божий, помилуй меня, грешного!») будет способствовать возвышению личности через постепенное обожение и принятие в качестве искупления своих грехов посылаемые на пути возвращения к Богу лишения и испытания; служение Имени Всепривлекающего Кришны (санскр. Харе Кришна Харе Кришна Кришна Кришна Харе Харе Харе Рама Харе Рама Рама Рама Харе Харе - «О энергия наслаждения всепривлекающего и всерадующего Господа, позволь мне с любовью и преданностью служить Ему!») будет способствовать возвышению личности через постепенное очищение сердца от эгоизма вплоть до раскрытия своего уникального положения в отношениях с Ним.

\footnotetext{
29 Там же. С. 76.
}

30 Лосев А.Ф. Вещь и имя. Самое само / подг. текста и общ. ред. А.А. Тахо-Годи, В.П. Троицкого; вступ. ст. А.Л. Доброхотова; комм. А.С. Яковлева. СПб.: Изд-во Олега Абышко, 2008. C. $182-183$. 


\section{Философия и психология}

Отсюда ясно, что буддист - это вовсе не слепой последователь Будды, но достойный ученик, для удовлетворения своего Совершенного Учителя развивающий такие качества, как разумность, сосредоточенность, уравновешенность и т.п.; мусульманин - это вовсе не униженный раб Аллаха, но достойный слуга, для удовлетворения своего Господина развивающий такие качества, как верность, надёжность, преданность и т.п.; христианин - это вовсе не изображающий мессию верующий во Христа, но достойный человек, для удовлетворения Бога развивающий такие качества, как терпение, сострадание, прощение и т. п.; вайшнав - это вовсе не тот, кто думает, что служит непосредственно Кришне, но достойный слуга слуги Его возлюбленных слуг, для удовлетворения преданных Кришны развивающий такие качества, как скромность, великодушие, искусность и т.п.

Приведённые примеры служения Имени в контексте различных религиозных традиций вовсе не излишни. Во-первых, они показывают присущую религиям специфику общих для них механизмов личностного становления и социокультурной преемственности ценностей, выраженную в развитии личностных качеств. Во-вторых, они отчасти объясняют существующую в философском наследии А.Ф. Лосева взаимосвязь категорий «имя», «миф», «истина». В обсуждаемых вопросах русский философ был не только теоретиком, но и практиком: его труды были, скорее, продиктованы стремлением передавать знания другим в крайне неблагоприятных для этого условиях, нежели стремлением отвлечённо теоретизировать на религиозные темы. Итак, А.Ф. Лосев анализирует слова Иисуса, приведённые в Евангелии от Иоанна (10:25), обращая внимание на греческий вариант текста: «творить дела так, чтобы в них являлся Отец», или чтобы на них почил образ Божий, идея Божественного существа» ${ }^{31}$. Глазами религии идёт речь о такого рода действиях, которые, с одной стороны, являются формой служения Богу, a, с другой стороны, - позволяют совершающему эти действия всегда помнить о Боге. Однако, по нашему мнению, русского философа интересовала не столько религиозная сторона вопроса, сколько само существо духовной реальности. Если религия зачастую искусственно регулирует и направляет действия человека посредством предписаний и запретов, то в мифе этого не требуется, поскольку личность естественно испытывает влечение ко всему тому, что в иной атмосфере предписывалось религией.

Взаимоотношения в мифе как социокультурном единстве поддерживаются естественным влечением к

31 Там же. С. 168-169.
Мифу - Личности, являющейся центром и основанием этого единства. Несомненно, Личности, известные нам под Именами «Кришна», «Будда», «Иисус Христос», в первую очередь должны характеризоваться в качестве Мифа - живого чуда, воплощённого совершенства, истинной реальности. А.А. Тахо-Годи так комментирует позицию А.Ф. Лосева по этому поводу: «Миф оказывается чудом и реальным предметом веры. Таковыми были Зевс и Гера, Деметра и Посейдон, Афины и Гефест, Аполлон и Артемида и т.д. и т.д. <...> Что может быть достовернее мифа, если, по Лосеву, он - образ бытия личностного и, сверх того, это лик личности, потому что слово (а по-гречески это и есть «миф»- что иное, как исторически ставшая личность» ${ }^{32}$. Харизма Мифа вовлекает в миф, побуждая раскрыть каждого соприкоснувшегося личное отношение к Абсолютной Истине как Личности. А.Ф. Лосев очень тонко понимал, что живой Миф не только историчен, но и представляет собой лакмусовую бумажку, выявляющую реальный масштаб личности, её духовную зрелость на настоящий момент времени. Миф никого не может оставить равнодушным, проводя принципиальное различие между божественными и демоничными натурами. «Однажды ощутивши ту Личность, универсальнее и абсолютнее которой ничего не может быть ни в прошлом, ни в настоящем, ни в будущем, человечество уже не могло забыть Её. Но помнить - не значит только любить. Помнить можно и в ненависти, в злобе, борьбе. Возрождение открывает собою тот период истории, когда человек будет ненавидеть Бога, злобствовать на Него, бороться с Ним. <..>> Мыслить Бога несуществующим вот наибольшая ненависть к Богу, вот наибольшая злоба против Него. < .. > Убить Бога и занять Его место - заветная мечта человека, лишь немногим более поздняя, чем мечта о всецелом подчинении» ${ }^{33}$.

Античная и средневековая философия совпадают в своем стремлении к Истине, которое также можно обозначить в качестве богоискательства, однако глубинные основания философского наследия А.Ф. Лосева, по нашему мнению, следует искать в философии Древнего мира. Парадоксально, но интуиция Древнего Востока прослеживается в большинстве его трудов. Н.А. Чупахина отмечает, что «образ взаимоопределения рационального и иррационального, света и тьмы у Лосева берётся скорее из буддизма (где свет и тьма выступают

32 Тахо-Годи А.А. Гомер, или чудо как реальный факт // Лосев А.Ф. Гомер / предисл. А.А. Тахо-Годи. 2-е изд., испр. М.: Молодая гвардия, 2006. С. 6.

33 Лосев А.Ф. Диалектика мифа. Дополнение к Диалектике мифа / сост., подг. текста, общ. ред. А.А. Тахо-Годи, В.П. Троицкого. М.: Мысль, 2001. С. 256. 


\section{Психология и психотехника 5(56) • 2013}

как два равных начала), чем из христианства» ${ }^{34}$. Однако в отличие от имперсонального буддизма, отвергающего существование души и Бога, А.Ф. Лосев придерживался исключительно персоналистского взгляда на эти вопросы. В связи с этим можно вспомнить, что А.Ф. Лосева не интересовали и не страшили французские материалисты, поскольку «гораздо безбожнее» для него были «верующий Декарт» и «трансценденталист Кант» ${ }^{35}$. Такая позиция русского мыслителя проявляет себя в решении важнейшей проблемы, раскалывающей древневосточную философию на два лагеря: если имперсоналисты считают, что вершиной духовного совершенствования является слияние с Богом, заключающееся в растворении души в безличном Абсолюте, то персоналисты, напротив, заключают, что достижение совершенства обязательно предполагает именно межличностные отношения. По мнению русского философа, «православный опыт и молитва, или призывание Имени Божия, как раз и опираются на реальное восприятие Бога человеческой личностью, так что и Бог, несмотря на конечное Его действие, остаётся непознаваемым, неизмеримым и нерасчленённым, и тварь, несмотря на то, что в ней уже ничего не остаётся, кроме Божественного, продолжает быть всё-таки тварью и не сливается с Богом по сущности» ${ }^{36}$. По сути, только персоналистская концепция допускает Миф как совершенную личность и миф как совершенную общность.

В «Са́мое само́» А.Ф. Лосева находим лейтмотив древнейшей персоналистской традиции бхакти - любовной преданности, предполагающей полную сосредоточенность сознания на служении Личности Бога своими чувствами, словами, поступками. Одухотворённость сознания личности и в бхакти, и в мифе достигается именно в постоянстве памятования с любовью о совершенной личности. Так, рассматривая каждую вещь в качестве символа са́мого самого́, А.Ф. Лосев по сути предполагает такое сознание личности, которое способно через различные символы постоянно находиться в общении с Истиной, в непосредственной связи с Ней. В этом случае весь окружающий мир со всем многообразием существующих в нём воспринимается иначе - как живой символ истины, потенциально являющийся её живым представителем.

34 Чупахина Н.А. Диалектика имени А.Ф. Лосева в контексте русской религиозной лингвофилософии: дисс. ... канд. философских наук: 09.00.03. СПб, 2007. С. 27.

35 Лосев А.Ф. Диалектика мифа. Дополнение к Диалектике мифа / сост., подг. текста, общ. ред. А.А. Тахо-Годи, В.П. Троицкого. М.: Мысль, 2001. С. 262.

36 Лосев А.Ф. Вещь и имя. Самое само / подг. текста и общ. ред. А.А. Тахо-Годи, В.П. Троицкого; вступ. ст. А.Л. Доброхотова; комм. А.С. Яковлева. СПб.: Изд-во Олега Абышко, 2008. C. 183.
Кроме того, определяя са́мое само́ в качестве абсолютной индивидуальности, находящейся в процессе самопроизвольного, самопорождающегося становления, философ подводит к идее об одновременном единстве и различии сущности $^{37}$. По его мнению, «всякая становящаяся вещь и весь человек с его свободной духовной деятельностью есть не что иное, как момент, выражение, излияние, действие и проч. только абсолютной самости» ${ }^{38}$. Множество конкретных примеров проявления такого сознания можно найти в трудах, раскрывающих науку и философию бхакти ${ }^{39}$. В свою очередь в трудах А.Ф. Лосева можно найти множество примеров аналогичных интуиций.

Так, например, древнеиндийскя философия последовательно обосновывает идею о майе - иллюзии, отвлекающей внимание личности от Бога. Русский философ в «Философии имени» развивает учение о меоне, а в «Диалектике мифа» обращает внимание на постепенный отход всё более и более рационального человека от Бога. Если находящийся в мире субъект Средневековья способен видеть в окружающей его природе символы, напоминающие ему о рае, то позднее отношение к природе становится расчётливо-эгоистичным. «Возрожденский субъект не нуждается в природе как в вещественном факте и субстанции (он есть субстанция и сам по себе, без помощи природы), но нуждается в природе как в предмете знания, чувства, воли, вообще своей интеллигенции» ${ }^{40}$. Сегодня можно наблюдать развитие подмеченной А.Ф. Лосевым тенденции: человек всё больше и больше уходит от реального мира в мир виртуальный, но уже полностью очищенный от Бога. Если в мире природы - пусть материальном, временном, конечном - человек всё-таки может увидеть символы божественного, вечного, бесконечного бытия, то в мире виртуальном его ждут только бесконечные страсти. Уже сегодня можно видеть примеры людей, оторванных от жизни миром Интернета с привлекательными, захватывающими и поглощающими личность играми (интеллектуальными, военными, экономическими или эротическими - в зависимости от того или иного уровня сознания личности).

Классический философский трактат Вьясы «Ведантасутра» начинается со слов «Атхато брахма джигьяса» («Настало время вопрошать об Абсолютной Истине»,

37 Там же. С. 233-235.

38 Там же. С. 247.

39 См.: Прабхупада А.Ч. Бхактиведанта Свами. Нектар преданности / пер. с англ. М.: Бхактиведанта Бук Траст, 1991. 511 с.; Прабхупада А.Ч. Бхактиведанта Свами. Источник вечного наслаждения / пер. с англ. М.: Бхактиведанта Бук Траст, 1989. 868 с.

40 Лосев А.Ф. Диалектика мифа. Дополнение к Диалектике мифа / сост., подг. текста, общ. ред. А.А. Тахо-Годи, В.П. Троицкого. М.: Мысль, 2001. С. 260. 


\section{Философия и психология}

Веданта-сутра, 1.1). Постижению природы души посвящены самые философские разделы Вед. Известный комментатор «Шримад-Бхагаватам» А.Ч. Бхактиведанта Свами Прабхупада отмечает: «Чтобы постичь природу души и её деятельность, мало просто понять, что мы не материальное тело, а духовная душа (ахам брахмасми: «По природе я - Брахман»). Для этого необходимо ещё действовать, как подобает Брахману» ${ }^{41}$. А.Ф. Лосев также нетривиально подходит к решению этой проблемы: «но если и душа моя - только моя, а не я сам, и если дух мой только мой, т.е. только принадлежит мне, а не я сам, то где же я, что такое это моё Я, са́мое само́, что во мне есть, я сам, уже ни на что не сводимый и сам в себе, без всякого инобытия?» ${ }^{42}$. Однако ответ А.Ф. Лосева на этот счёт: «Я есть Я - вот последняя мудрость, которую мы только можем здесь проявить» ${ }^{43}-$ не может быть принят как удовлетворительный и окончательный теми, кто углублённо исследовал его философское наследие.

Взгляд на философское наследие А.Ф. Лосева из XXI в. фокусируется на его понимании чуда: критерием проявления чуда в человеческой жизни не является ни приложение волевых усилий, ни превосходство в чём бы то ни было над другими, ни развитие таких личностных качеств, как нравственность, чувство долга, ответственность. Глубоким убеждением Алексея Фёдоровича
Лосева, свидетельствующим о результативности его личного духовного опыта, является понимание беспричинности милости Бога к человеку: «чудо может совершиться с преступником, вопреки всей его жизни и личности» ${ }^{44}$. Эта позиция предполагает такое сознание, которое позволяет личности быть в мифе постоянно: находиться в полной зависимости от Мифа как Абсолютной Личности, преданно служить Имени и при этом стремиться к Истине каждой мыслью, каждым словом и каждым поступком. Так или иначе, но главным индикатором качества жизни личности является смерть. В частности, одна из шлок «Бхагавад-Гиты» гласит: «О каком бы состоянии бытия ни думало живое существо в момент смерти, этого состояния бытия оно достигает непременно» (8.6). Последним словом Алексея Фёдоровича Лосева можно считать продиктованное накануне смерти «Слово о Кирилле и Мефодии», в котором мы находим ответ на поставленный в начале этого текста вопрос: «...но иной раз где-то в глубине души у меня звучит таинственный голос, и я слышу пение церковного тропаря, возвещающего мою подлинную реальную общность: «Яко апостолом единонравнии и словенских стран учителие, Мефодие и Кирилле богомудрии, Владыку всех молите мир вселенней даровати и душам нашим велию милость» ${ }^{45}$.

\section{Список литературь:}

1. Бибихин В.В. Алексей Федорович Лосев. Сергей Сергеевич Аверинцев. М.: Институт философии, теологии и истории св. Фомы, 2006. 416 с.

2. Булгаков С.Н. Философия Имени. СПб.: Наука, 1998. 448 с.

3. Гусев Д.В. Влияние исихастских традиций на философскую антропологию П.А. Флоренского и А.Ф. Лосева: дисс. ... канд. философских наук: 09.00.03. Орел, 2001. 196 с.

4. Кассирер Э. Философия символических форм. Т. 2: Мифологическое мышление. М.; СПб.: Университетская книга, 2002. 280 с.

5. Лосев А.Ф. Античная философия в ее историческом развитии. М.: Государственное учебно-педагогическое издательство, 1957.620 с.

6. Лосев А.Ф. Античный космос и современная наука // Бытие - Имя - Космос / сост. и ред. А.А. Тахо-Годи. М.: Мысль, 1993. С. 61-612.

7. Лосев А.Ф. Вещь и имя. Самое само / подг. текста и общ. ред. А.А. Тахо-Годи, В.П. Троицкого; вступ. ст. А.Л. Доброхотова; комм. А.С. Яковлева. СПб.: Изд-во Олега Абышко, 2008. 576 с.

8. Лосев А.Ф. Диалектика мифа. Дополнение к Диалектике мифа / сост., подг. текста, общ. ред. А.А. Тахо-Годи, В.П. Троицкого. М.: Мысль, 2001. 558 с.

9. Лосев А.Ф. Очерки античного символизма и мифологии / сост. и общ. ред. А.А. Тахо-Годи. СПб.: Алетейя, 1993. 959 с.

41 Прабхупада А.Ч. Бхактиведанта Свами. Шримад-Бхагаватам. Третья песнь: Статус кво: главы 24-33. М.: Бхактиведанта Бук Траст, 1993. С. 64.

42 Лосев А.Ф. Вещь и имя. Самое само / подг. текста и общ. ред. А.А. Тахо-Годи, В.П. Троицкого; вступ. ст. А.Л. Доброхотова; комм. А.С. Яковлева. СПб.: Изд-во Олега Абышко, 2008. C. 206.

43 Там же. С. 208.
44 См. подробнее: Лосев А.Ф. Диалектика мифа. Дополнение к Диалектике мифа / сост., подг. текста, общ. ред. А.А. Тахо-Годи, В.П. Троицкого. М.: Мысль, 2001. С. 195-196.

45 См.: Тахо-Годи Е.А. Царственное слово // Российская газета. Федеральный выпуск № 5485 (109). С. 10; Лосев А.Ф. Реальность общего. Слово о Кирилле и Мефодии // Литературная газета. 1988. 8 июня. 


\section{Психология и психотехника 5(56) • 2013}

10. Лосев А.Ф. Реальность общего. Слово о Кирилле и Мефодии // Литературная газета. 1988. 8 июня.

11. Лосев А.Ф. Эстетика хороводов в «Законах» Платона // Античность и современность. М.: Наука, 1972. С. 133-153.

12. Омельчук Р.К. Онтология веры в философском наследии А.Ф. Лосева // Психология и психотехника. 2011. № 11 (38). C. $15-25$.

13. Петраков А.А. Проблема символа в русской философии XX века (П.А. Флоренский, А.Ф. Лосев, С.Н. Булгаков, А. Белый): дисс... канд. философских наук: 09.00.13. М., 2006. 162 с.

14. Прабхупада А.Ч. Бхактиведанта Свами. Источник вечного наслаждения / пер. с англ. М.: Бхактиведанта Бук Траст, 1989. $868 \mathrm{c}$.

15. Прабхупада А.Ч. Бхактиведанта Свами. Нектар преданности / пер. с англ. М.: Бхактиведанта Бук Траст, 1991.511 с.

16. Прабхупада А.Ч. Бхактиведанта Свами. Шримад-Бхагаватам. Третья песнь: Статус кво: главы 24-33. М.: Бхактиведанта Бук Траст, 1993. 622 с.

17. Тахо-Годи А.А. Гомер, или чудо как реальный факт // Лосев А.Ф. Гомер / предисл. А.А. Тахо-Годи. 2-е изд., испр. М.: Молодая гвардия, 2006. С. 5-8.

18. Тахо-Годи Е.А. Царственное слово // Российская газета. Федеральный выпуск № 5485 (109). С. 10.

19. Флоренский П.А. Философия культа. Опыт православной антроподицеи / сост. и коммент. С.М. Половинкин, игумен Андроник (Трубачев). М.: Российская политическая энциклопедия (РОССПЭН), 2010. 568 с.

20. Чупахина Н.А. Диалектика имени А.Ф. Лосева в контексте русской религиозной лингвофилософии: дисс... канд. философских наук: 09.00.03. СПб, 2007. 179 с.

\section{References (transliteration):}

1. Bibihin V.V. Aleksey Fedorovich Losev. Sergey Sergeevich Averincev. M.: Institut filosofii, teologii i istorii sv. Fomy, 2006. $416 \mathrm{~s}$.

2. Bulgakov S.N. Filosofiya Imeni. SPb.: Nauka, 1998. $448 \mathrm{s.}$

3. Gusev D.V. Vliyanie isihastskih tradiciy na filosofskuyu antropologiyu P.A. Florenskogo i A.F. Loseva: diss... kand. filosofskih nauk: 09.00.03. Orel, 2001. $196 \mathrm{s.}$

4. Kassirer E. Filosofiya simvolicheskih form. T. 2: Mifologicheskoe myshlenie. M.; SPb.: Universit. kn., 2002. 280 s.

5. Losev A.F. Antichnaya filosofiya v ee istoricheskom razvitii. M.: Gosudarstvennoe uchebno-pedagogicheskoe izdatel'stvo, 1957. $620 \mathrm{~s}$.

6. Losev A.F. Antichnyy kosmos i sovremennaya nauka // Bytie - Imya - Kosmos / sost. i red. A.A. Taho-Godi. M.: Mysl', 1993. S. 61-612.

7. Losev A.F. Vesch' i imya. Samoe samo / podg. teksta i obsch. red. A.A. Taho-Godi, V.P. Troickogo; vstup. st. A.L. Dobrohotova; komm. A.S. Yakovleva. SPb.: Izd-vo Olega Abyshko, 2008. 576 s.

8. Losev A.F. Dialektika mifa. Dopolnenie k Dialektike mifa / sost., podg. teksta, obsch. red. A.A. Taho-Godi, V.P. Troickogo. M.: Mysl', 2001. $558 \mathrm{~s}$.

9. Losev A.F. Ocherki antichnogo simvolizma i mifologii / sost. i obsch. red. A.A. Taho-Godi. SPb.: Aleteyya, 1993. 959 s.

10. Losev A.F. Real'nost' obschego. Slovo o Kirille i Mefodii // Literaturnaya gazeta. 1988. 8 iyunya.

11. Losev A.F. Estetika horovodov v «Zakonah» Platona // Antichnost' i sovremennost'. M.: Nauka, 1972. S. 133-153.

12. Omel'chuk R.K. Ontologiya very v filosofskom nasledii A.F. Loseva // Psihologiya i psihotehnika. 2011. № 11 (38). S. 15-25.

13. Petrakov A.A. Problema simvola v russkoy filosofii HH veka (P.A. Florenskiy, A.F. Losev, S.N. Bulgakov, A. Belyy): diss... kand. filosofskih nauk: 09.00.13. M., 2006. $162 \mathrm{~s}$.

14. Prabhupada A.Ch. Bhaktivedanta Svami. Istochnik vechnogo naslazhdeniya; per. s angl. M.: Bhaktivedanta Buk Trast, 1989. $868 \mathrm{~s}$.

15. Prabhupada A.Ch. Bhaktivedanta Svami. Nektar predannosti / per. s angl. M.: Bhaktivedanta Buk Trast, 1991. $511 \mathrm{~s}$.

16. Prabhupada A.Ch. Bhaktivedanta Svami. Shrimad-Bhagavatam. Tret'ya pesn': Status kvo: glavy 24-33. M.: Bhaktivedanta Buk Trast, 1993. $622 \mathrm{~s}$.

17. Taho-Godi A.A. Gomer, ili chudo kak real'nyy fakt // Losev A. F. Gomer / predisl. A.A. Taho-Godi. 2-e izd., ispr. M.: Molodaya gvardiya, 2006. S. 5-8.

18. Taho-Godi E.A. Carstvennoe slovo // Rossiyskaya gazeta. Federal'nyy vypusk № 5485 (109). S. 10.

19. Florenskiy P.A. Filosofiya kul'ta. Opyt pravoslavnoy antropodicei / sost. i komment. S.M. Polovinkin, igumen Andronik (Trubachev). M.: Rossiyskaya politicheskaya enciklopediya (ROSSPEN), 2010. $568 \mathrm{~s}$.

20. Chupahina N.A. Dialektika imeni A.F. Loseva v kontekste russkoy religioznoy lingvofilosofii: diss... kand. filosofskih nauk: 09.00.03. SPb, 2007. $179 \mathrm{~s}$. 